\title{
IMPLEMENTASI KARTU KREDIT PEMERINTAH PADA KANTOR PELAYANAN PERBENDAHARAAN NEGARA AMLAPURA
}

\author{
Sriyani $^{1}$, I Ketut Bhawa Samudra ${ }^{2}$, Bernadine Dwi Arrya Syahputra ${ }^{3}$ \\ ${ }^{1,2}$ Kebendaharaan Negara, Politeknik Keuangan Negara STAN, ${ }^{3}$ Universitas Raharja \\ sriyani@pknstan.ac.id, ketut.samudra00@gmail.com
}

\begin{abstract}
Abstrak
Pemanfaatan teknologi terbukti efisien dan efektif dalam membantu melakukan aktifitas organisasi. Semua sektor memanfaatkan adanya teknologi untuk mempermudah aktivitas, tak terkecuali sektor keuangan pemerintah. Saat ini pemerintah Indonesia sudah menerapkan kartu plastik dalam pelaksanaan pembayaran Anggaran Pendapatan dan Belanja Negara (APBN). Salah satu penggunaan kartu plastik pada pemerintah adalah kartu kredit pemerintah (KKP). Penelitian ini menggunkan metode kualitatif, pengumpulan data dilakukan dengan wawancara dengan pihak-pihak yang terkait pengelolaan KKP pada KPPN Amlapura. Penelitian ini diharapkan dapat memberikan gambaran implementasi KKP pada KPPN Amlapura. Berdasarkan hasil tinjauan yang telah penulis lakukan terhadap implementasi Kartu Kredit Pemerintah pada KPPN Amlapura telah dilaksanakan dengan baik dan cukup optimal yaitu pada proses pengajuan, penagihan, dan penyelesaian tagihan KKP. Untuk penatausahaan bukti-bukti masih belum sesuai peraturan yang berlaku. Dampak positif dari implementasi KKP antara lain bendahara pengeluaran tidak harus memegang banyak uang karena sudah berbentuk kartu kredit, sehingga pengelolaan UP lebih efektif karena mengurangi adanya idle cash. Kedua, transaksi UP lebih transparan karena seluruh transaksi sudah termuat dalam tagihan/billing statement yang dikirimkan secara periodik ke email administrator KKP. sehingga percepatan penyerapan anggaran dapat dilaksanakan dengan lebih optimal. Namun masih terdapat permasalahan yang dihadapi KPPN Amlapura terkait penyediaan Elektronik Data Capture (EDC) dan pemenuhan SDM dan secara kuantitas maupun kualitas.
\end{abstract}

Kata Kunci: Implementasi, KKP, Perbendaharaan

\begin{abstract}
Technology has proven to be efficient and effective in helping to carry out organizational activities. All sectors use technology to facilitate activities, including the government financial sector. Currently, the Indonesian government has implemented a plastic card in the implementation of payments for the State Budget. One of the uses of plastic cards by the government is the government credit card. This study uses a qualitative method, data collection is carried out by interviewing parties related to the management of KKP at KPPN Amlapura. This research is expected to provide an overview of the implementation of the KKP at KPPN Amlapura. Based on the results that have been achieved, the author has carried out the implementation of the Government Credit Card at KPPN Amlapura which has been carried out optimally, namely in the process of submitting, billing, and paying KKP. For the administration of evidence, it is still not in accordance with applicable regulations. The positive impact of the implementation of the KKP includes activities that do not have to hold a lot of money because it is in the form of a credit card, so that the management of UP is more effective because there is no idle cash. Second, UP transactions are more transparent because all transactions are already included in the bill/billing statement which is sent periodically to the KKP administrator's email. so that the acceleration of the budget can be implemented more optimally. However, there are still problems faced by KPPN Amlapura related to the provision of Electronic Data Capture (EDC) and the fulfillment of human resources and quantity and quality.
\end{abstract}

Keywords: Implementation, KKP, Treasury

\section{Pendahuluan}

Teknologi semakin hari semakin canggih, saat ini hampir seluruh aspek kehidupan sangat erat kaitannya dengan pemanfaaatan teknologi. Pemanfaatan teknologi ini terbukti efisien dan efektif dalam membantu melakukan aktifitas sehari 
hari. Semua sektor memanfaatkan adanya teknologi untuk mempermudah aktivitas, tak terkecuali sektor keuangan juga memanfaatkannya.

Pemanfaatan teknologi pada sektor keuangan salah satunya adalah penggunaan kartu plastik sebagai penganti uang dan sebagai alat pembayaran. Kartu plastik terbukti lebih aman dan praktis, serta dapat diterima di berbagai tempat bahkan hingga kelevel internasional. Selain itu pemilik kartu plastik juga dapat menguangkan saldo yang terdapat pada kartunya melalui bank penerbit atau ATM.

Saat ini pemerintah Indonesia sudah menerapkan kartu plastik dalam pelaksanaan pembayaran Anggaran Pendapatan dan Belanja Negara (APBN). Salah satu penggunaan kartu plastik pada pemerintah adalah kartu kredit pemerintah (KKP). Penggunaan KKP merupakan amanat Peraturan Pemerintah (PP) Nomor 50 Tahun 2018 Pasal 66 ayat 5 yang ditetapkan tanggal 7 Desember 2018 tentang Perubahan Atas PP 45 Tahun 2013 tentang Tata Cara Pelaksanaan Anggaran. Pendapatan dan Belanja Negara. Pada pasal tersebut disebutkan bahwa "Ketentuan mengenai Tata Cara Pembayaran dan Penggunaan Kartu Kredit diatur dengan Peraturan Menteri Keuangan". Atas dasar PP tersebut, Menteri Keuangan menerbitkan Peraturan Menteri Keuangan (PMK) Nomor 178/PMK.05/2018 yang ditetapkan tanggal 26 Desember 2018 tentang Perubahan atas PMK Nomor 190/PMK.05/2012 tentang Tata Cara Pembayaran Dalam Rangka Pelaksanaan Anggaran Pendapatan dan Belanja Negara. Pada Pasal 46 ayat 7 PMK tersebut dijelaskan bahwa "Ketentuan mengenai Penggunaan dan Pembayaran UP melalui Kartu Kredit Pemerintah diatur dengan Peraturan Menteri Keuangan tersendiri". Setelah ditetapkannya PMK tersebut, Menteri Keuangan kembali menetapkan PMK Nomor 196/PMK.05/2018 pada tanggal 31 Desember 2018 tentang Tata Cara Pembayaran dan Penggunaan Kartu Kredit Pemerintah dimana PMK tersebut mengatur mengenai tata cara pembayaran dan penggunaan Kartu Kredit Pemerintah dalam penyelesaian tagihan kepada negara melalui mekanisme UP selain Satker Perwakilan Republik Indonesia di luar negeri dan Satker Atase Teknis.

Latar belakang dari penggunaan KKP ini adalah sebagai upaya pemerintah untuk menyempurnakan mekanisme pembayaran APBN dan perlunya modernisasi pembayaran secara non tunai pada sistem pembayaran APBN. Penggunaan KKP ini juga bertujuan agar dalam pembayaran APBN penggunaan uang tunai dapat diminimalisir, memberikan keamanan pada saat bertransaksi, mencegah terjadinya fraud dari transaksi secara tunai, dan mengurangi adanya idle cash dari penggunaan uang persediaan (UP). Pada PMK Nomor 196/PMK.05/2018 juga disebutkan bahwa penggunaan KKP memperhatikan prinsip-prinsip sebagai berikut. Pertama, fleksibel yaitu adanya kemudahan pada saat menggunakan kartu karena memiliki jangkauan pemakaian yang lebih luas dan dapat dilakukan di seluruh merchant yang menyediakan pembayaran dengan mesin Electronic Data Capture (EDC) serta media daring. Kedua, keamaman dalam bertransaksi serta menghindari adanya penyimpangan (fraud) pada transaksi secara tunai. Ketiga, efektif untuk mengurangi kas/UP yang menganggur (idle cash) dan biaya dana (cost of fund) pemerintah dari transaksi menggunakan UP. Terakhir, akuntabilitas atas pembayaran tagihan pemerintah dan pembebanan biaya penggunaan UP KKP.

Selain itu penggunaan KKP juga dimaksudkan untuk mendukung pelaksanaan prinsip-prinsip pengelolaan keuangan negara. Prinsip pengelolaan keuangan negara dalam Undang-undang Nomor 17 Tahun 2003 Tentang Keuangan Negara yaitu "Keuangan Negara dikelola secara tertib, taat pada peraturan perundang-undangan, efisien, ekonomis, efektif, transparan, dan bertanggung jawab dengan memperhatikan 
rasa keadilan dan kepatutan". Dengan digunakannya KKP sebagai alat pembayaran APBN diharapkan pengelolaan keuangan negara dapat terlaksana sesuai prinsip diatas.

KKP berdasarkan PMK Nomor 196/PMK.05/2018 merupakan sebuah kartu yang dapat digunakan untuk melakukan transaksi belanja atas beban APBN, dimana kewajiban pembayaran terlebih dahulu dipenuh oleh pihak bank penerbit KKP, dan satker wajib untuk melunasi kewajiban pembayaran tersebut pada waktu yang telah ditentukan. KKP merupakan bagian dari uang persediaan (UP) yang dikelola oleh bendahara pengeluaran. Bendahara Pengeluaran adalah seseorang yang ditugaskan untuk menerima, menyimpan, membayarkan, menatausahakan, dan mempertanggungjawabkan uang untuk keperluan belanja negara pada Kementerian/Lembaga. Sedangkan, UP adalah uang muka kerja yang diberikan kepada BP yang akan digunakan untuk membiayai keperluan sehari-hari satker atau pengeluaran yang tidak dapat dilakukan dengan mekanisme pembayaran langsung (LS). Proporsi dari UP yang diberikan kepada bendahara pengeluaran adalah UP Tunai sebesar $60 \%$ dan UP KKP sebesar 40\%, dimana proporsi atas UP tersebut dapat dirubah dengan persetujuan dari Kepala Kanwil DJPb.

Penerapan UP KKP tergolong baru sehingga dalam pelaksanannya terdapat berbagai kendala yang ditemui. Uji coba penggunaan UP KKP ini dilakukan pada tahun 2017 melalui penerbitan Peraturan Direktur Jenderal Perbendaharaan Nomor 17/PB/2017. Kendala yang dihadapi antara lain sebagai berikut. Pertama, pola pikir aparatur pemerintah. Mengingat kebiasaan penggunaan uang tunai dalam bertransaksi, perlu adanya perubahan pola pikir aparatur pemerintah ketika sudah diimplementasikannya transaksi keuangan dengan KKP (non tunai) sehingga implementasi KKP dapat berjalan secara optimal. Kedua, ketersediaan mesin EDC yang terbatas. Mengingat luasnya daerah Indonesia, dimana tidak semua daerah memiliki perekonomian yang maju, sehingga ketersediaan teknologi seperti mesin EDC yang digunakan dalam bertransaksi KKP masih terbatas sehingga menyebabkan penerapan KKP belum dapat dilakukan secara penuh. Ketiga, pemahaman surcharge. Peraturan Bank Indonesia No. 11/11/PBI/2009 tentang Penyelenggaraan Kegiatan Alat Pembayaran dengan Menggunakan Kartu menegaskan bahwa praktek pengenaan biaya tambahan transaksi (surcharge) dalam transaksi kartu kredit menyalahi aturan. Saat ini, praktek ini masih sering terjadi karena masih banyak pemahaman merchant yang kurang serta bank penerbit kartu kredit yang tidak tegas (Syaefudin, 2019).

Karangasem merupakan sebuah kabupaten yang berlokasi di timur pulau Bali. Selama ini belum ada tinjauan tentang penggunaan KKP di Karangasem sehingga penulis akan melakukan tinjauan atas implementasi Kartu Kredit Pemerintah pada KPPN Amlapura. Tinjauan yang akan penulis lakukan berfokus pada proses implementasi KKP, implementasi KKP sebagai alat pembayaran, permasalahan yang dihadapi, serta langkah penyelesaian masalah yang dilakukan oleh KPPN Amlapura.

\section{Landasan Teoritis}

Berdasarkan KBBI, Implementasi berarti pelaksanaan atau penerapan. Sedangkan menurut Mulyadi (2015), implementasi merupakan tindakan-tindakan untuk mengubah keputusan-keputusan menjadi sebuah kegiatan tertentu untuk mencapai tujuan yang telah ditetapkan sebelumnya.

Ripley and Franklin menuliskan tentang dua pendekatan untuk menilai Implementasi kebijakan dengan menyatakan: 
There are two principal of assessing implementation. One approach focuses on compliance. It asks whether implementers comply with prescribed procedures, timetables, and restrictions. The compliance perspective sets up a preexisting model of correct implementation behavior and measures actual behavior against it. The second approach toassessing implementation proceding. What is it achieving? Why? This perspective can be characterized as inductive or empirical. Less elegantly, the central questions are what's happening? And why?

Implementasi kebijakan menurut Ripley dan Franklin dilihat dari dua pendekatan: 1. Kepatuhan

Keberhasilan Implementasi kebijakan diukur dengan melihat tingkat kepatuhan, baik tingkat bawahan terhadap atasan maupun kepatuhan pelaksana kebijakan (implementers) terhadap peraturan yang diberikan. Terdapat 2 indikator pendekatan kepatuhan yaitu perilaku pelaksana kebijakan dan pemahaman pelaksana kebijakan terhadap kebijakan

2. Apa yang terjadi dan mengapa?

Pendekatan ini melihat bagaimana implementasi berlangsung serta untuk melihat faktorfaktor penyebab yang mempengaruhi suatu program. Ripley dan Franklin mengatakan ada 5 indikator dalam menjelaskan pendekatan ini. Menurut Ripley and Franklin lima fitur yang paling penting yang dibahas dalam kelanjutan bab ini yaitu, banyaknya aktor yang terlibat, kejelasan tujuan, kompleksitas program pemerintah, partisipasi unit pemerintahan di semua tingkat wilayah, dan faktor-faktor yang mempengaruhinya.

Dalam pelaksanaan anggaran belanja negara, kepala Satker atas pendelegasian kewenangan dari Menteri/Pimpinan Lembaga menunjuk bendahara pengeluaran (BP) dan apabila diperlukan menunjuk bendahara pengeluaran pembantu (BPP) untuk melaksanaakan tugas kebendaharaan. Salah satu tugas kebendaharaan yaitu pengelolaan uang dan/atau surat berharga yang berasal dari uang persediaan (UP).

Menurut pasal 43 Peraturan Menteri Keuangan Nomor 178/PMK.05/2018 Tentang Perubahan atas Peraturan Menteri Keuangan Nomor 190/PMK.05/2012 tentang Tata Cara Pembayaran dalam Rangka Pelaksanaan Anggaran Pendapatan dan Belanja Negara, Uang persedian atau UP merupakan uang muka kerja yang diberikan oleh kuasa BUN kepada BP untuk mendanai keperluan sehari-hari satker dan membiayai pengeluaran yang tidak dapat dilakukan dengan mekanisme Langsung (LS). Belanja dengan UP dapat dilakukan untuk belanja barang, belanja modal, dan belanja lain-lain.

Pembayaran yang dilakukan melalui UP oleh bendahara dapat dilakukan paling banyak Rp50.000.000,00. Hal ini dikecualikan untuk pembayaran honorarium dan perjalanan dinas. Untuk pembayaran melalui UP yang melebihi Rp50.000.000,00 dapat dilakukan setelah disetujui oleh Menteri Keuangan c.q. Direktur Jenderal Perbendaharaan. Setelah UP sudah digunakan sebesar 50\% maka bendahara perngeluaran dapat melakukan pengisian kembali (revolving) uang persediaannya selama pagu dalam DIPA untuk UP masih tersedia.

Untuk memperoleh UP, KPA mengajukan kebutuhan operasional yang akan dibayarkan melalui UP untuk 1 bulan kepada KPPN. Besaran UP yang diberikan dijelaskan pada tabel II.1.

Tabel 1. Besaran Uang Persediaan

\begin{tabular}{|c|c|}
\hline Besaran UP Per Bulan (Maks.) & $\begin{array}{c}\text { Pagu Jenis Belanja Yang Bisa Dibayarkan Melalui } \\
\text { UP }\end{array}$ \\
\hline Rp100.000.000,00 & Sampai dengan Rp2.400.000.000,00 \\
\hline Rp200.000.000,00 & Rp2.400.000.000,00 s.d Rp6.000.000.000,00 \\
\hline Rp500.000.000,00 & Diatas Rp6.000.000.000,00 \\
\hline
\end{tabular}


Sumber: Diolah dari PMK Nomor 178/PMK.05/2018.

Uang Persediaan yang diajukan oleh bendahara dibagi menjadi dua jenis yaitu UP Tunai dan UP KKP. Besaran UP tunai yang diberikan adalah sebesar $60 \%$ dari total UP, sedangkan besaran UP KKP sebesar $40 \%$ dari total UP. Perubahan besaran UP dan proporsi UP KKP dan UP tunai dapat dilakukan apabila telah memperoleh persetujuan dari Kepala Kantor Wilayah Direktorat Jenderal Perbendaharaan. Khusus untuk satker yang pada wilayah kerjanya tidak terdapat penyedia yang melayani pembayaran dengan KKP dan memiliki pagu jenis belanja yang dapat dibayarkan dengan UP sampai dengan Rp2.400.000.000,00 dapat mengajukan UP tunai sebesar 100\%.

KKP dapat dibagi menjadi 2 jenis yaitu kartu kredit untuk keperluan belanja barang operasional serta belanja modal dan kartu kredit untuk keperluan belanja perjalanan dinas jabatan. Satker dapat memiliki satu atau kedua jenis KKP dari satu bank penerbit.

Untuk setiap jenis kartu kredit yang dimiliki, diberikan batasan belanja (limit) untuk satu bulan. Limit untuk kartu kredit belanja operasional dan modal untuk pertama kali paling banyak sebesar Rp50.000.000,00, sedangkan untuk limit kartu kredit perjalanan dinas untuk pertama kali paling banyak sebesar Rp20.000.000,00. Total limit untuk semua kartu kredit yang dimiliki satker paling banyak sebesar UP KKP yang dimiliki oleh satker. Limit tersebut nantinya dapat dilakukan penambahan secara permanen/sementara kepada bank penerbit dengan terlebih dahulu mendapat persetjuan dari KPA.

Pemegang KKP adalah pejabat atau pegawai pada kementerian/Lembaga yang ditetapkan oleh KPA yang ditugaskan untuk melakukan transaksi UP dengan menggunakan KKP. Sedangkan, Administrator KKP adalah pejabat atau pegawai pada kementerian/Lembaga yang ditetapkan oleh KPA yang ditugaskan untuk untuk melakukan tugas tertentu terkait dengan pengelolaan dan penggunaan KKP.

Pemegang KKP berbeda untuk tiap jenis kartu kredit. Kartu kredit belanja operasional dan modal dipegang oleh pejabat pengadaan barang dan jasa, pejabat struktural, pelaksana, atau pegawai lainnya yang bertugas dalam pengadaan barang dan jasa. Sedangkan, kartu kredit perjalanan dinas dipegang oleh pejabat atau pegawai yang melaksanakan perjalanan dinas.

\section{Proses Pengajuan, Penerbitan, dan Penyerahan KKP}

Pengajuan KKP diawali dengan perjanjian kerja sama induk antara DJPb dengan kator pusat bank penerbit KKP. Setelah melakuan kerjasama induk, KPA kemudian membuat perjanjian kerja sama satker dengan bank yang ditunjuk untuk menerbitkan KKP.

Berdasarkan perjanjian kerjasama yang telah dibuat oleh satker, PPK kemudian menyampaikan usulan pemegang dan administrator KKP dengan jumlah sesuai kebutuhan satker kepada KPA. Atas dasar usulan tersebut, KPA dapat menyetujui usulan dengan menerbitkan surat keputusan KPA yang berisikan daftar KKP dan daftar Administrator KKP.

KPA mengajukan permohonan penerbitan KKP kepada bank penerbit disertai dengan dokumen pendukung kemudian diverifikasi oleh bank penerbit yang dilakukan paling lambat 6 hari kerja setelah surat permohonan tersebut diterima. Apabila hasil verifikasi tersebut terpenuhi maka bank penerbit menerbitkan dan menyampaikan KKP, rekapitulasi penerbitan KKP, dan tanda terima KKP kepada KPA. Apabila hasil 
verifikasi tersebut tidak terpenuhi maka bank penerbit berhak untuk menolak sebagian/seluruh permohonan KKP dengan menerbitkan surat pemberitahuan penolakan dan disampaikan paling lambat 1 hari kerja setelah verifikasi selesai dilakukan. Setelah KKP diterima oleh satker, KPA menyerahkan KKP kepada pemegang KKP. Penyerahan ini dikuti dengan penandatanganan BAST dan surat perjanjian penggunaan KKP oleh pemegang KKP dan KPA.

Gambar 1. Alur Pembayaran Dengan KKP

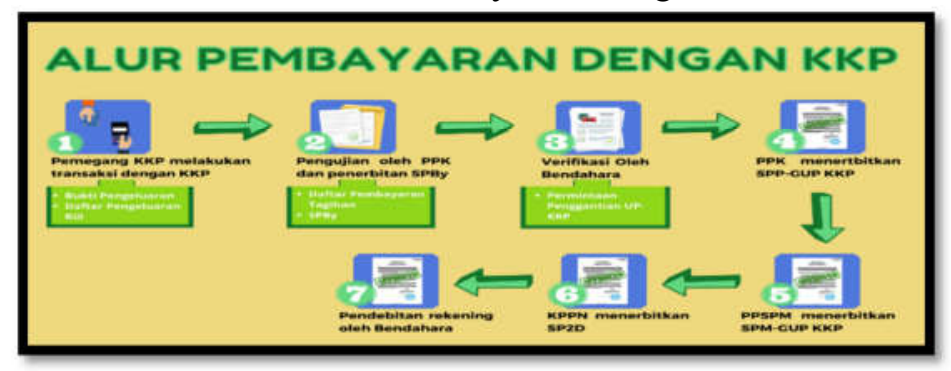

Sumber: Diolah penulis dari Buku Pintar KKP Jilid 2

Berdasarkan PMK Nomor 196/PMK.05/2018 Tentang Tata Cara Pembayaran dan Penggunaan Kartu Kredit Pemerintah, proses pembayaran belanja dengan menggunakan UP KKP adalah sebagai berikut.

1. Pemegang KKP melakukan transaksi KKP pada penyedia yang menyediakan mesin EDC (Electronic Data Capture) atau pada e-marketplace. Atas transaksi yang dilakukan, pemegang KKP mengumpulkan dokumen berupa bukti transaksi pengeluaran, tagihan (e-billing) dan daftar tagihan sementara dari bank, surat tugas, surat pejalanan dinas, atau kontrak. Dokumen diatas termasuk bukti-bukti penerimaan negara seperti faktur pajak dan Surat Setoran Pajak (SSP). Berdasarkan dokumen transaksi yang sudah dikumpulkan pemegang KKP, kemudian dibuat Daftar Pengeluaran Riil belanja operasional dan modal serta Daftar Pengeluaran Riil belanja perjalanan dinas.

2. PPK melakukan pengujian atas Daftar Pengeluaran Riil yang diserahkan oleh pemegang KKP. Atas pengujian yang dilakukan, PPK mengesahkan bukti pengeluaran dan menerbitkan Daftar Pembayaran Tagihan (DPT) KKP. Berdasarkan DPT tersebut, PPK atas nama KPA kemudian menerbitkan SPBy dan disampaikan kepada BP/BPP. Apabila dalam pengujian yang dilakukan ditemukan bukti pengeluaran yang tidak sesuai dengan ketentuan, PPK menolak bukti pengeluaran tersebut.

3. Atas SPBy tersebut, BP/ BPP melakukan pengujian atas SPBy, ketersediaan dana UP KKP, dan menyusun daftar pungutan/potongan pajak/bukan pajak. Apabila telah memenuhi persyaratan, maka BP/ BPP menyerahkan SPBy, daftar pungutan/potongan pajak/bukan pajak, beserta dokumen lainnya kepada PPK untuk selanjutnya dilakukan pengantian UP KKP. Apabila SPBy tidak memenuhi persyaratan, maka SPBy dikembalikan kepada PPK.

4. PPK menerbitkan dan menyampaikan SPP-GUP KKP kepada PPSPM.

5. PPSPM melakukan pengujian atas SPP-GUP KKP beserta dokumen pendukung. Atas pengujian tersebut, apabila sudah sesuai, maka diterbitkan SPM-GUP KKP dan disampaikan kepada KPPN. Apabila tidak sesuai, maka SPP-GUP dikembalikan kepada PPK. 
6. KPPN melakukan pengujian SPM-GUP KKP yang telah diserahkan oleh PPSPM. KPPN menerbitkan SP2D apabila SPM GUP tersebut telah memenuhi ketentuan dan mengembalikan SPM-GUP apabila tidak memenuhi ketentuan.

7. Setelah SP2D terbit, BP melakukan pendebitan rekening BP ke rekening Bank Penerbit KKP. Pendebitan dapat dilakukan melalui layanan perbankan secara elektronik atau cek/bilyet giro.

\section{Metode}

Metode penelitian yang digunakan adalah kualitatif dengan pendekatan studi kasus yang Jenis, Sumber, dan Metode Pengumpulan Data Penelitian ini berfokus dalam meninjau kesesuaian implementasi data yang diperoleh di lapangan terhadap kebijakan dan peraturan yang mengikat data tersebut. Data yang digunakan dalam penelitian ini merupakan data primer yang diperoleh langsung dari KPPN Amplapura.

Metode pengumpulan data yang digunakan adalah studi kepustakaan dan studi lapangan. Studi kepustakaan yang dilakukan penulis bertujuan untuk memperoleh informasi terkait latar belakang dan kajian teoritis. Studi kepustakaan yang penulis gunakan yaitu peraturan perundang-undangan mengenai kartu kredit pemerintah dan dokumen-dokumen berupa jurnal, buku, dan jurnal penelitian terdahulu yang berkaitan dengan penerapan kartu kredit pemerintah. Studi Lapangan dilakukan dengan cara wawancara. Wawancara bertujuan untuk menggali informasi yang lebih mendalam dari objek. Partisipan yang terlibat pada wawancara ini yaitu Bendahara Pengeluaran, Pejabat Pengadaan, dan Administrator KKP pada KPPN Amlapura.

\section{Hasil dan Pembahasan}

Kantor Pelayanan Perbendaharaan Negara (KPPN) Amlapura adalah instansi vertikal Direktorat Jenderal Perbendaharaan Kementerian Keuangan yang berkedudukan di bawah Kantor Wilayah Direktorat Jenderal Perbendaharaan Provinsi Bali. Pada awal pendiriannya, KPPN Amlapura belum memiliki Gedung kantor sendiri. Pada saat itu KPPN Amlapura menempati Gedung yang dipinjam dari Pemerintah Kabupaten Karangasem yaitu Gedung Kantor Perusahaan Daerah Air Minum (PDAM) Amlapura di Jalan Ngurah Rai, Amlapura. Pada tanggal 17 Oktober 2003, Setelah diresmikannya Gedung KPPN Amlapura yang terletak di Jalan Cempaka, Amlapura, KPPN Amlapura resmi memiliki dan menempati Gedung kantor sendiri. Peresmian Gedung ini dilakukan oleh Sekretaris Direktur Jenderal Perbendaharaan Bapak Drs. Dharma Bakti, MA.

Visi yang dimiliki oleh KPPN Amlapura adalah menjadi pelaksana fungsi Bendahara Umum Negara yang professional, transparan, dan akuntabel untuk mewujudkan pelayanan prima. Untuk mencapai hal tersebut, misi yang ditetapkan yaitu:

a. Menjamin kelancaran pencairan dana APBN secara tepat sasaran, tepat waktu, dan tepat jumlah.

b. Mengelola penerimaan negara secara professional dan akuntabel.

c. Mewujudkan pelaporan pertanggungjawaban APBN yang akurat dan tepat waktu.

Berdasarkan Peraturan Menteri Keuangan Nomor 262/PMK.01/2016 tentang Organisasi dan Tata Kerja Kantor Vertikal Direktorat Jenderal Perbendaharaan, KPPN Amlapura merupakan KPPN Tipe A2 yang mempunyai tugas sebagai berikut:

a. Melaksanakan kewenangan perbendaharaan dan bendahara umum negara;

b. Penyaluran pembiayaan atas beban anggaran; dan 
c. Penatausahaan penerimaan dan pengeluaran anggaran melalui dan dari kas negara berdasarkan peraturan perundangan.

Untuk melaksanakan tugas tersebut, KPPN Amlapura menyelenggarakan fungsi sebagai berikut:

a. Pengujian terhadap surat perintah pembayaran berdasarkan peraturan perundangundangan;

b. Penerbitan Surat Perintah Pencairan Dana (SP2D) dari kas negara atas nama Menteri Keuangan selaku Bendahara Umum Negara;

c. Penyaluran pembiayaan atas beban APBN;

d. Penilaian dan pengesahan terhadap penggunaan uang yang telah disalurkan;

e. Penatausahaan penerimaan dan pengeluaran negara melalui dan dari Kas Negara;

f. Pengiriman dan penerimaan kiriman uang;

g. Penyusunan laporan pelaksanaan anggaran pendapatan dan belanja negara;

h. Penyusunan laporan realisasi pembiayaan yang berasal dari pinjaman dan hibah luar negeri;

i. Penatausahaan Penerimaan Negara Bukan Pajak;

j. Penyelenggaraan verifikasi transaksi keuangan dan akuntansi;

k. Pembuatan tanggapan dan penyelesaian temuan hasil pemeriksaan;

1. Pelaksanaan kehumasan; dan

m. Pelaksanaan administrasi KPPN.

\section{Implementasi Kartu Kredit Pemerintah di KPPN Amlapura.}

Selain bertugas sebagai Kuasa Bendahara Umum Negara (BUN), KPPN Amlapura juga memiliki peran sebagai Satker Pengguna Anggaran. Sebagai Satker Pengguna Anggaran, KPPN Amlapura memiliki belanja-belanja untuk melaksanakan tugasnya seperti Belanja Pegawai, Belanja Barang, dan Belanja Modal. Dalam melaksanakan belanja tersebut, KPPN Amlapura menggunakan mekanisme Pembayaran Langsung (LS) dan pembayaran dengan Uang persediaan (UP). Mekanisme UP biasanya digunakan untuk belanja-belanja dengan nilai paling banyak Rp50.000.000,00 seperti pembelian ATK dan perjalanan dinas. Transaksi dengan mekanisme UP tersebut dapat dilakukan dengan pembayaran tunai, kartu debit, internet banking, serta KKP.

Dalam pelaksanaan anggaran belanja negara, bendahara pengeluaran (BP) KPPN Amlapura mengelola uang persediaan (UP) yang terdiri dari UP Tunai dengan proporsi sebesar $60 \%$ dan UP KKP dengan proporsi sebesar 40\%. Besaran UP tersebut tertuang dalam surat persetujuan UP yang diterbitkan oleh KPPN Amlapura. Pada tahun anggaran 2020, UP yang dikelola BP KPPN Amlapura adalah sebesar Rp50.000.000,00 yang terdiri dari UP Tunai sebesar Rp30.000.000,00 dan UP KKP sebesar Rp20.000.000,00. Berikut tabel persetujuan besaran UP KPPN Amlapura.

Tabel 2. Persetujuan UP KPPN Amlapura

\begin{tabular}{|c|l|c|}
\hline No. & \multicolumn{1}{|c|}{ Uraian } & Jumlah (Rp) \\
\hline 1 & Pagu DIPA & 1.774 .886 .000 \\
\hline 2 & $\begin{array}{l}\text { Pagu Jenis Belanja yang dapat dibayarkan melalui UP } \\
\text { dalam 1 tahun }\end{array}$ & 1.564 .133 .000 \\
\hline 3 & $\begin{array}{l}\text { Pagu Jenis Belanja yang dapat dibayarkan melalui UP } \\
\text { Tunai dalam 1 tahun }\end{array}$ & 938.479 .800 \\
\hline 4 & $\begin{array}{l}\text { Pagu Jenis Belanja yang dapat dibayarkan melalui UP } \\
\text { KKP dalam 1 tahun }\end{array}$ & 625.653 .200 \\
\hline 5 & Besaran UP Satker per bulan & 50.000 .000 \\
\hline 6 & $\begin{array}{l}\text { Perubahan Besaran UP melampaui Besaran UP Satker } \\
\text { per bulan }\end{array}$ & 0 \\
\hline 7 & Besaran UP Tunai (60\%) & 30.000 .000 \\
\hline 8 & Besaran UP KKP (40\%) & 20.000 .000 \\
\hline
\end{tabular}


Sumber Data: Diolah dari Arsip KPPN Amlapura

Proporsi UP Tunai dan UP KKP yang dimiliki oleh KPPN Amlapura sesuai dengan proporsi UP pada PMK 196/PMK.05/2018 yaitu 60\% untuk UP Tunai dan $40 \%$ untuk UP KKP. Proporsi ini sebenarnya dapat dilakukan perubahan jika sudah memperoleh persetujuan dari Kepala Kantor Wilayah Direktorat Jenderal Perbendaharaan. Namun, pada KPPN Amlapura, proporsi ini tidak dilakukan perubahan dikarenakan dengan proporsi yang ada sudah mencukupi kebutuhan operasional KPPN Amlapura.

Uang persediaan ini kemudian digunakan untuk pengeluaran keperluan operasional sehari-hari KPPN Amlapura. Untuk UP tunai, setelah digunakan sebesar $50 \%$, bendahara perngeluaran akan melakukan pengisian kembali UP. Sedangkan, untuk UP KKP langsung bisa dilakukan pengisian kembali UP setelah melakukan transaksi. Jadi, tidak perlu menunggu digunakan sebesar 50\% sudah bisa melakukan pengisian kembali UP. Pengisian kembali UP dilakukan dengan cara mengajukan Surat Perintah Membayar (SPM) GUP Tunai atau SPM GUP KKP ke KPPN mitra kerja.

Atas transaksi menggunakan UP yang dilakukan KPPN Amlapura, BP KPPN Amlapura melakukan pembukuan yang terdiri dari Buku Kas Umum (BKU), Buku Pembantu (BP), dan Buku Pengawasan Anggaran. BP KPPN Amlapura juga menyusun Laporan Pertanggungjawaban (LPJ) Bendahara Pengeluaran setiap bulannya. LPJ Bendahara Pengeluaran yang telah disusun kemudian disampaikan kepada KPPN mitra kerja paling lambat tanggal 10 bulan berikutnya. LPJ tersebut merupakan pertanggungjawaban atas penggunaan UP Tunai yang dikelola oleh BP KPPN Amlapura. UP KKP tidak dimasukkan kedalam UP yang dikelola bendahara dalam LPJ Bendahara Pengeluaran, karena UP KKP tidak dipegang secara langsung oleh Bendahara (hanya berupa limit).

Pengajuan KKP ini dilakukan dengan pembuatan perjanjian kerjasama antara KPPN Amlapura dan PT Bank Rakyat Indonesia (Persero), TBK pada tanggal 24 Juni 2019. Berdasarkan perjanjian kerjasama tersebut, KPA KPPN Amlapura menerbitkan Surat Keputusan KPA KPPN Amlapura yang berisikan pemegang KKP dan administrator KKP.

Berdasarkan PMK Nomor 196/PMK.05/2018, Pemegang dan Administrator KKP adalah pejabat/ pegawai Satker yang berstatus sebagai Pejabat Negara, Pegawai Negeri Sipil, Prajurit TNI/POLRI. Hal ini telah sesuai yang diimplementasikan oleh KPPN Amlapura. Pemegang KKP Belanja Operasional dan Modal, pemegang KKP Perjalanan Dinas, dan Administrator KKP merupakan seorang Pegawai Negeri Sipil sesuai dengan bidang tugasnya.

Setelah ditetapkan pemegang dan administrator KKP, KPA KPPN Amlapura mengajukan permohonan penerbitan KKP kepada Bank BRI disertai dengan dokumen pendukung berupa surat referensi, formular aplikasi KKP, fotokopi KTP, fotokopi NPWP, fotokopi surat persetujuan besaran UP dari KPPN, dan fotokopi surat keputusan penunjukan KPA pada tanggal 27 Juni 2019. Setelah KKP diterbitkan dan diterima oleh KPPN Amlapura, KPA kemudian menyerahkan KKP kepada pemegang KKP dengan penandatanganan BAST dan surat perjanjian penggunaan KKP pada tanggal 27 November 2019. Setelah proses penyeran KKP ini selesai, KKP mulai bisa digunakan untuk pembayaran belanja.

Proses pengajuan KKP yang dilakukan oleh KPPN Amlapura telah sesuai dengan PMK Nomor 196/PMK.05/2018. Proses yang dilakukan meliputi pembuatan perjanjian 
kerjasama antara KPPN Amlapura dan PT Bank Rakyat Indonesia (Persero), TBK, Bank yang ditujuk untuk menerbitkan KKP KPPN Amlapura juga merupakan Bank yang sama tempat BP KPPN Amlapura membuka Rekening Bendahara Pengeluaran. KPA KPPN Amlapura menerbitkan Surat Keputusan KPA KPPN Amlapura yang berisikan pemegang KKP dan administrator KKP. Kemudian, KPA KPPN Amlapura mengajukan permohonan penerbitan KKP kepada Bank BRI. Langkah yang terahkir adalah penandatanganan BAST dan surat perjanjian penggunaan KKP oleh KPA dan Pemegang KKP.

\section{Penggunaan Kartu Kredit Pemerintah Sebagai Alat Pembayaran}

KKP pada KPPN Amlapura terdiri dari 2 jenis KKP yaitu KKP Belanja Operasional dan Modal serta KKP Belanja Perjalanan Dinas. KKP yang mendominasi transaksi pada KPPN Amlapura adalah KKP Belanja Operasional dan Modal. KKP ini digunakan untuk Belanja Barang Operasional, Belanja Barang Non Operasional, dan Belanja Barang untuk Persediaan. Belanja Barang Operasional dapat berupa belanja keperluan perkantoran, belanja pengadaan makanan, dan belanja penambah daya tahan tubuh.

Belanja menggunakan KKP Belanja Operasional dan Modal KPPN Amlapura pada tahun 2020 di dominasi oleh Belanja Barang Non Operasional. Belanja yang dilakukan oleh KPPN Amlapura sudah sesuai dengan jenis belanja yang ditetapkan pada PMK Nomor 196/PMK.05/2018. PMK tersebut menjelaskan bahwa belanja yang dapat dibayarkan dengan KKP Belanja Operasional dan Modal yaitu Belanja barang operasional, seperti belanja keperluan perkantoran dan bahan makanan, belanja barang non operasional seperti belanja bahan, belanja barang untuk persediaan, belanja sewa, belanja pemeliharaan gedung dan bangunan, peralatan dan mesin serta pemeliharaan lainnya, dan belanja modal paling banyak Rp50.000.000,00.

Pada KPPN Amlapura KKP Belanja Perjalanan Dinas sangat jarang digunakan oleh KPPN Amlapura. Hal ini disebabkan oleh frekuensi perjalanan dinas KPPN Amlapura tidak terlalu sering. Selain itu, belanja perjalanan dinas pada KPPN Amlapura adalah perjalanan dinas dalam kota. Sehingga, hanya dapat membayarkan uang harian saja dan tidak bisa dibayar menggunakan KKP. Berdasarkan PMK Nomor 196/PMK.05/2018, KKP Belanja Perjalanan Dinas hanya dapat digunakan untuk membayar biaya transport, biaya penginapan, dan biaya sewa angkutan dalam kota. Sampai dengan saat ini KKP Belanja Perjalanan Dinas pada KPPN Amlapura sudah pernah digunakan sekali untuk pembayaran penginapan.

Dalam melakukan transaksi menggunakan KKP, KPPN Amlapura memiliki Standar Prosedur Operasi (SOP) internal, yang diterbitkan pada tanggal 2 Januari 2020 melalui Surat Keputusan KPA Satker KPPN Amlapura Nomor Kep33/WPB.22/KP.03/2020 tentang Penetapan Standar Prosedur Operasi Penggunaan, Penyelesaian Tagihan, dan Pertanggungjawaban KKP pada KPPN Amlapura. Selain berpedoman pada SOP tersebut, KPPN Amlapura juga tetap mengacu pada PMK Nomor 178/PMK.05/2018 tentang tentang Perubahan atas PMK Nomor 190/PMK.05/2012 tentang Tata Cara Pembayaran Dalam Rangka Pelaksanaan Anggaran Pendapatan dan Belanja Negara dan PMK Nomor 196/PMK.05/2018 tentang Tata Cara Pembayaran dan Penggunaan Kartu Kredit Pemerintah.

Berdasarkan SOP Penggunaan KKP KPPN Amlapura, pemegang KKP melakukan transaksi melalui merchant yang menerima pembayaran melalui mesin EDC atau melalui marketplace. Transaksi pada merchant EDC dilakukan dengan menggesek kartu 
kredit pada mesin EDC. Sedangkan, transaksi melalui marketplace dilakukan dengan pemilihan cara pembayaran menggunakan KKP pada saat pemilihan tata cara pembayaran.

Atas transaksi yang dilakukan, pemegang KKP kemudian mengumpulkan dan menatausahakan bukti pengeluaran menggunakan KKP berupa kwitansi, nota atau bukti pembelian lainnya yang diterbitkan oleh pihak penyedia barang/jasa. Bukti pengeluaran yang ditatausahakan termasuk faktur pajak, Surat Setoran Pajak (SSP) yang merupakan lampiran dari kwitansi/bukti pembelian dari penyedia barang/jasa. Penyimpanan bukti transaksi KKP oleh pengguna KKP dapat dilakukan secara manual dan secara elektronik.

Selain mengumpulkan bukti pengeluaran, pemegang KKP KPPN Amlapura juga mengumpulkan daftar tagihan dari bank tempat KKP diterbitkan. Daftar tagihan ini merupakan seluruh transaksi yang dilakukan pada periode sebelumnya yang kemudian harus dilunasi oleh KPPN Amlapura.

Berdasarkan PMK Nomor 196/PMK.05/2018, daftar tagihan yang diberikan oleh pihak bank harus memuat nama pemegang KKP, nomor KKP (account number), tanggal cetak Daftar Tagihan Sementara, tanggal transaksi (transaction date), tanggal pembukuan (posting date), keterangan (description), nilai transaksi (amounts), dan sub total tagihan. Daftar tagihan yang diberikan oleh pihak bank kepada KPPN Amlapura sudah sesuai dengan peraturan yang berlaku.

Pada PMK Nomor 196/PMK.05/2018, dijelaskan bahwa setelah pemegang KKP mengumpulkan bukti pengeluaran dan daftar dagihan dari bank, pemegang KKP membuat Daftar Pengeluaran Riil Kegiatan Operasional Dan Belanja Modal dengan KKP dan/ atau Daftar Pengeluaran Riil Kegiatan Perjalanan Dinas Jabatan dengan KKP. Daftar Pengeluaran Riil tersebut dibuat berdasarkan format yang tercantum dalam lampiran PMK 196/PMK.05/2018. Daftar Pengeluaran Riil beserta lampiran berupa bukti pengeluaran dan daftar tagihan tersebut selanjutnya diserahkan kepada PPK untuk dilakukan pengujian. Namun, pada KPPN Amlapura, pembuatan Daftar Pengeluaran Riil Kegiatan Operasional Dan Belanja Modal dengan KKP dan/ atau Daftar Pengeluaran Riil Kegiatan Perjalanan Dinas Jabatan dengan KKP tidak dilakukan. Menurut Bendahara Pengeluaran KPPN Amlapura, hal ini tidak dilakukan karena nilai dan jenis transaksi yang dilakukan dengan KKP sudah termuat dalam bukti pengeluaran dan daftar tagihan dari bank.

\section{Penagihan dan Penyelesaian Tagihan}

Bukti transaksi dan tagihan dari bank yang sudah terkumpul kemudian diserahkan kepada PPK oleh pemegang KKP pada KPPN Amlapura. PPK kemudian melakukan pengujian atas dokumen yang diserahkan oleh pemegang KKP. Setelah pengujian selesai, PPK mengesahkan bukti pengeluaran dan menerbitkan Daftar Pembayaran Tagihan (DPT) KKP.

PMK 196/PMK.05/2018 mengatur format pembuatan DPT yang dibuat oleh PPK. Berdasarkan format DPT yang telah disusun oleh PPK KPPN Amlapura, DPT ini telah sesuai dengan format yang tercantum pada lampiran PMK 196/PMK.05/2018. Namun, ada beberapa bagian yang tidak diisi oleh KPPN Amlapura sesuai yang diatur dalam PMK 196/PMK.05/2018 yaitu pengisian kolom Nama Pemegang KKP dan kolom Nomor KKP.

Berdasarkan DPT tersebut, PPK kemudian menerbitkan SPBy paling lambat 2 hari setelah DPT diterbitkan untuk selanjutnya disampaikan kepada BP. Berikut adalah 
contoh SPBy yang diterbitkan oleh PPK KPPN Amlapura dalam rangka penyelesaian tagihan pembayaran dengan KKP.

Berdasarkan PMK 196/PMK.05/2018, SPBy yang disusun oleh PPK paling sedikit memuat tanggal dan nomor SPBy, jumlah tagihan Kartu Kredit Pemerintah yang dibayarkan, nomor rekening Bank Penerbit Kartu Kredit, peruntukkan pembayaran, dasar pembayaran, pembebanan anggaran, dan tanggal setuju/lunas bayar serta penandatangan SPBy. Berdasarkan SPBy yang diterbitkan KPPN Amlapura, terdapat ketidaksesuaian dengan PMK 196/PMK.05/2018 yaitu tidak terdapat nomor rekening bank penerbit Kartu Kredit Pemerintah pada SPBy tersebut. Hal ini dikarenakan penyusunan SPBy KPPN Amlapura mengacu kepada PMK Nomor 190/PMK.05/2012. Berikut format SPBy pada PMK Nomor 190/PMK.05/2012.

Setelah BP KPPN Amlapura menerima SPBy dari PPK, BP kemudian melakukan pengujian atas SPBy, pengujian ketersediaan dana UP KKP, dan penyusunan daftar pungutan/potongan pajak/bukan pajak atas tagihan dalam SPBy. Setelah pengujian selesai dilakukan, BP menyerahkan SPBy beserta dokumen pendukung yang sudah ditandatangani kepada PPK untuk selanjutnya dilakukan pengantian UP KKP.

Penggantian UP KKP dimulai dengan penerbitan SPP-GUP KKP oleh PPK dan disampaikan kepada PPSPM. PPSPM kemudian melakukan pengujian atas SPP-GUP KKP tersebut dan menerbitkan SPM-GUP KKP serta menyampaikannya kepada KPPN mitra kerja. Pengajuan dokumen SPP-GUP KKP/SPM-GUP KKP ini terpisah dari pengajuan SPP/GUP Tunai/SPM-GUP Tunai. Hal ini sudah sesuai dengan PMK 196/PMK.05/2018. Dokumen SPP dapat dilihat pada lampiran 9 dan SPM GUP KKP.

Setelah SP2D GUP KKP diterbitkan oleh KPPN dan dana sudah diterima pada rekening BP, BP melakukan pembayaran atas tagihan kartu kredit kepada bank melalui Cash Management System (CMS). Besaran nominal pembayaran yang dilakukan adalah sebesar yang tertera pada tagihan bank penerbit KKP. Sampai dengan saat ini, KPPN Amlapura belum pernah mengalami keterlambatan dalam penyelesaian tagihan KKP. Keterlambatan dalam penyelesaian tagihan KKP akan dikenakan sanksi sesuai dengan perjanjian yang telah dibuat.

Berdasarkan PMK 196/PMK.05/2018, sebelum melakukan pembayaran tagihan KKP kepada bank penerbit, BP melakukan pemungutan/pemotongan pajak/bukan pajak dan melakukan penyetoran ke Kas Negara. Hal ini telah disesuaikan melalui peraturan baru yaitu PMK Nomor 231 /PMK.03/2019 Tentang Tata Cara Pendafaran dan Penghapusan Nomor Pokok Wajib Pajak, Pengukuhan dan Pencabutan Pengukuhan Pengusaha Kena Pajak, Serta Pemotongan dan/Atau Pemungutan, Penyetoran, dan Pelaporan Pajak Bagi Instansi Pemerintah. Dalam PMK tersebut dijelaskan bahwa, instansi pemerintah tidak melakukan pemungutan PPh Pasal 22 dan PPN atas pembayaran yang menggunakan KKP. Peraturan ini berlaku mulai tanggal 1 April 2020. Jadi atas transaksi menggunakan KKP sejak tanggal 1 April 2020, KPPN Amlapura tidak lagi melakukan pemungutan pajak PPh Pasal 22 dan PPN.

\section{Permasalahan pelaksanaan KKP di KPPN Amlapura.}

Pada tahun 2019 KPPN Amlapura sudah mulai melakukan transaksi menggunakan KKP. Pada saat implementasi KKP, KPPN Amlapura menemui beberapa kendala yang mengganggu jalannya implementasi KKP. Berdasarkan keterangan dari Bendahara Pengeluara (BP), Pemegang KKP, dan Administrator KKP KPPN Amlapura, terdapat 4 kendala yang ditemui yaitu sebagai berikut. 
Pertama, merchant yang menyediakan mesin electronic data capture (EDC) masih terbatas. Kabupaten Karangasem yang terletak diujung timur Pulau Bali dapat dikatakan bukan merupakan kota besar. Masyarakat masih cenderung melakukan transaksi dengan uang tunai atau transfer, sehingga penyedia barang dan jasa enggan untuk meyediakan mesin EDC. Hal ini berpengaruh kepada ketersediaan mesin EDC yang digunakan dalam bertransaksi KKP sangat terbatas sehingga menyebabkan penerapan KKP belum optimal. Ini menunjukkan bahwa pada KPPN Amlapura, prinsip fleksibilitas dari penggunaan KKP sebagai alat pembayaran belum terpenuhi.

Kedua, pembayaran tagihan/billing statement KKP melalui teller seringkali masih dikenakan biaya diluar bea materai. Menurut keterangan Bendahara KPPN Amlapura, berdasarkan ketentuan yang berlaku, penggunaan KKP seharusnya tidak dikenakan lagi biaya tambahan/surcharge. Berdasarkan pasal 19 huruf o PMK Nomor 196/PMK.05/2018, penggunaan KKP bebas dari biaya pembayaran tagihan baik melalui teller, ATM, maupun e-banking. Dalam kenyataanya ada beberapa teller bank yang masih mengenakan biaya tambahan pada saat pembayaran tagihan melalui teller. Hal ini jelas tidak sesuai dengan peraturan yang berlaku. Atas kendala ini, KPPN Amlapura sering mendapat keluhan dari satker yang mengimplementasikan KKP, karna kebanyakan dari satker terbebut melakukan pembayaran tagihan melalui teller, akhirnya banyak satker jadi enggan menggunakan KKP.

Ketiga, perlu adanya customer service khusus KKP di setiap cabang bank penerbit KKP. Berdasarkan pengalaman dari KPPN Amlapura, untuk proses permintaan perubahan limit, pengaktifan/pengnonaktifan KKP, dan permintaan perubahan pemegang KKP memakan waktu yang cukup lama. Hal ini tentu saja akan menghambat penggunaan KKP, karena untuk proses perubahan tersebut yang tidak segera diselesaikan. Saat ini, sudah ada call center khusus untuk melayani penggunaan KKP. Namun, tetap saya prosesnya memakan waktu yang cukup lama, karena konsultasi pasti di eskalasi ke Jakarta (pusat) dan informasi untuk call center tersebut masih terbatas sehingga banyak satker yang tidak tahu. Customer service khusus KKP di setiap cabang Bank diperlukan untuk meningkatkan layanan.

Keempat, terdapat kendala dalam pengurusan perubahan email admin KKP. KPPN Amlapura beberapa kali telah melakukan usulan perubahan email admin KKP kepada bank penerbit KKP. Namun, sampai dengan saat ini, billing statement masih dikirimkan ke email admin KKP yang sebelumnya.

Disamping permasalahan yang ditemui, terdapat pula dampak positif yang ditimbulkan dari penggunaan KKP sebagai alat pembayaran. Berdasarkan keterangan dari Bendahara Pengeluara (BP) dan Pemegang KKP KPPN Amlapura, terdapat beberapa dampak positif dari implementasi KKP. Pertama, bendahara pengeluaran tidak harus memegang banyak uang karena sudah berbentuk kartu kredit, sehingga pengelolaan UP lebih efektif karena mengurangi adanya idle cash. Kedua, transaksi UP lebih transparan karena seluruh transaksi sudah termuat dalam tagihan/billing statement yang dikirimkan secara periodik ke email administrator KKP. Ketiga, tidak ada kewajiban pemungutan pajak atas transaksi menggunakan KKP yang diatur dengan PMK 231/PMK.03/2019 yang berlaku mulai tahun 2020. Sehingga, secara penatausahaan penggunaan KKP menjadi lebih aman dan praktis. Keempat, memiliki vendor yang lebih luas yaitu dari seluruh Indonesia karena bisa bertransaksi lewat $e$ marketplace. Sehingga, bisa leluasa memilih barang yang berkualitas dan harga yang lebih rendah. Kelima, penggunaan KKP sebagai alat pembayaran lebih efektif karena 
revolving dapat dilakukan dengan cepat tidak perlu menunggu $50 \%$, sehingga percepatan penyerapan anggaran dapat dilaksanakan dengan lebih optimal.

Selain itu, penggunaan KKP sangat bermanfaat di masa pandemi Covid-19. Menurut Indah dkk (2020), pembayaran non tunai atau cashless sangat bermanfaat dalam pencegahan penyebaran virus Corona. Hal ini dikarenakan penggunaan uang tunai sebagai metode pembayaran memiliki risiko penularan virus Corona. KPPN Amlapura juga menggunakan KKP dengan frekuensi yang semakin banyak untuk menghindari risiko penularan virus Corona. Hal ini dibuktikan dengan adanya peningkatan jumlah transaksi menggunakan KKP dari tahun 2019 (sebelum adanya pandemi Covid-19) dengan 4 SPM ke 2020 (setelah adanya pandemi Covid-19) dengan 9 SPM. Transaksi yang dilakukan oleh KPPN Amlapura melalui pendebitan KKP pada mesin EDC dan melalui e-marketplace.

\section{Penyelesaian Masalah yang Timbul dalam Implementasi KKP di KPPN Amlapura}

Implementasi KKP pada KPPN Amlapura menemui berbagai kendala. Kendala ini membuat implementasi KKP pada KPPN Amlapura tidak bisa dijalankan secara optimal. Saat ini KPPN Amlapura telah mengambil beberapa langkah untuk mengatasi kendala yang ditemui. Berikut adalah langkah-langkah penyelesaian masalah dalam penggunaan KKP yang diambil oleh KPPN Amlapura.

Pertama, untuk mengatasi kurangnya penyedia mesin EDC, KPPN Amlapura mencoba bertransaksi pada toko modern seperti Indomaret dan Alfamart. Namun, Indomaret dan Alpamart hanya menerima pembayaran dengan KKP untuk pembelian barang saja. Sedangkan, untuk belanja jasa seperti listrik menggunakan KKP tidak diterima oleh toko tersebut. Solusi lainnya adalah KPPN Amlapura mencari penyedia lain yang menyediakan mesin EDC. Saat ini, KPPN Amlapura punya 1 penyedia dan itupun adalah penyedia yang didorong oleh KPPN Amlapura agar menerima pembayaran dengan KKP. Untuk mengatasi kurangnya penyedia yang memiliki mesin EDC, pemerintah memberikan solusi dengan adanya marketplace. Marketplace tersebut memungkinkan satker untuk melakukan transaksi dengan penyedia yang lebih banyak, karena pada marketplace terdapat penyedia dari seluruh Indonesia. Untuk mengoptimalkan penggunaan KKP, pemerintah perlu melakukan kerjasama dengan pihak bank, agar pihak bank memberikan sosialisasi kepada penyedia di wilayah sekitar satker untuk menyediakan layanan pembayaran EDC.

Kedua, untuk mengatasi pembayaran tagihan billing statement KKP melalui teller yang seringkali dikenakan biaya diluar bea materai, KPPN Amlapura melakukan pembayaran melalui CMS sehingga tidak ada pemungutan biaya tambahan. KPPN Amlapura juga menyarankan kepada satker pengguna KKP untuk melakukan proses pendaftaran CMS ke bank sehingga untuk pembayaran tagihan KKP tidak dikenakan biaya tambahan. Untuk mengatasi permasalahan ini, pemerintah hendaknya memastikan PMK Nomor 196/PMK.05/2018 benar-benar terinformasikan secara menyeluruh kepada pihak terkait, agar tidak ada lagi pemungutan biaya penggunaan KPP selain bea materai.

Ketiga, untuk mengatasi kendala pengurusan perubahan email admin KKP yang tidak kunjung selesai, KPPN Amlapura secara terus-menerus memastikan perumahan email tersebut telah ditindak lanjuti oleh pihak bank penerbit KKP. Hal ini dilakukan agar proses perubahan email yang dilakukan dapat diselesaikan dengan cepat oleh pihak bank. Mengingat, hal ini sangat berpengaruh kepada proses penggunaan KKP karena daftar tagihan/billing statement akan dikirimkan ke email tersebut. 


\section{Kesimpulan}

Berdasarkan hasil tinjauan yang telah penulis lakukan terhadap implementasi Kartu Kredit Pemerintah pada KPPN Amlapura, dapat diambil simpulan bahwa Implementasi KKP pada KPPN Amlapura telah dilaksanakan dengan baik dan cukup optimal.

Proses pengajuan KKP pada KPPN Amlapura telah sesuai dengan PMK Nomor 196/PMK.05/2018 yang meliputi pembuatan perjanjian kerjasama antara KPPN Amlapura dan Bank BRI, penerbitan Surat Keputusan KPA yang mengatur pemegang KKP dan administrator KKP, pengajuan permohonan penerbitan KKP kepada Bank $\mathrm{BRI}$, dan penandatanganan BAST serta surat perjanjian penggunaan KKP oleh KPA dan Pemegang KKP.

KKP Belanja Operasional dan Modal mendominasi transaksi pada KPPN Amlapura. KKP tersebut digunakan untuk Belanja Bahan, Belanja Langganan Daya dan Jasa, Belanja Barang Persediaan Barang Konsumsi, dan Belanja Keperluan Perkantoran. KKP Belanja Perjalanan Dinas sangat jarang digunakan oleh KPPN Amlapura karena belanja perjalanan dinas pada KPPN Amlapura adalah perjalanan dinas dalam kota yang tidak bisa dibayarkan dengan KKP.

Penatausahaan bukti-bukti oleh pemegang KKP KPPN Amlapura belum sesuai dengan PMK 196/PMK.05/2018. Pemegang KKP KPPN Amlapura hanya mengumpulkan dan menatausahakan bukti pengeluaran dan tagihan dari bank. Sedangkan Daftar Pengeluaran Riil Kegiatan Operasional Dan Belanja Modal dengan KKP dan/ atau Daftar Pengeluaran Riil Kegiatan Perjalanan Dinas Jabatan dengan KKP tidak dilakukan pembuatan.

Penagihan dan Penyelesaian Tagihan KKP yang dilakukan telah sesuai dengan peraturan yang berlaku, meskipun terdapat sedikit permasalahan. Penagihan dan penyelesaian tagihan meliputi pengujian dokumen dari pemegang KKP oleh PPK, PPK mengesahkan bukti pengeluaran dan menerbitkan Daftar Pembayaran Tagihan (DPT) KKP, dan PPK menerbitkan SPBy dan disampaikan kepada BP. Pada saat pembuatan DPT ada beberapa bagian yang tidak diisi sesuai yang diatur dalam PMK 196/PMK.05/2018 yaitu pengisian kolom Nama Pemegang KKP dan kolom Nomor KKP. Penggantian UP KKP yang dilakukan telah sesuai dengan peraturan yang berlaku, Pengajuan SPP-GUP KKP/SPM-GUP KKP dilakukan secara terpisah dari pengajuan SPP/GUP Tunai/SPM-GUP Tunai. Setelah SP2D GUP KKP diterbitkan oleh KPPN dan dana sudah diterima pada rekening BP, BP melakukan pembayaran atas tagihan kartu kredit kepada bank melalui Cash Management System (CMS). Atas transaksi menggunakan KKP, KPPN Amlapura tidak lagi melakukan pemungutan pajak PPh Pasal 22 dan PPN yang diatur melalui PMK Nomor 231/PMK.03/2019.

\section{Daftar Pustaka}

Direktorat Jenderal Perbendaharaan. (2019). Buku pintar KKP jilid 2. Direktorat Jenderal Perbendaharaan Kementerian Keuangan Republik Indonesia

Indah,A.Y., Setiawati,I., Indiworo,H.E.(2020). Analisis Keputusan Nasabah Menggunakan Transaksi Non Tunai di Era Pandemi Covid 19 (Studi Kasus Pada Bank BRI Unit Sale Kabupaten Rembang). Jurnal Infokam, 16(2), 105-115.

Jonathan, Sarwono. (2006). Metode penelitian kuantitatif dan kualitatif. Graha Ilmu. Ripley, R. B. G. A. F. (1986). Policy Implementation and Bereaucracy. Chicago: Dorsey Press. 
Sugiono. (2009). Metode penelitian pendekatan kuantitatif, kualitatif dan $R \& D$. Alfa Beta.

Supardi, M.D. (2006). Metodologi penelitian. Yayasan Cerdas Press.

Syaefudin.A. (27 Maret 2019). Implementasi kartu kredit pemerintah: antara harapan dan tantangan. Koran Kaltara. https://korankaltara.com/implementasi-kartukredit-pemerintah-antara-harapan-dan-tantangan/

\section{Dokumen Publik atau Peraturan Perundang-Undangan}

Pemerintah Republik Indonesia. (2003). Undang-undang Republik Indonesia nomor 17 tahun 2003 tentang keuangan negara.

Pemerintah Republik Indonesia. (2018). Peraturan Menteri Keuangan Republik Indonesia nomor 178 tahun 2018 tentang perubahan atas Peraturan Menteri Keuangan nomor 190 tahun 2012 tentang tata cara pembayaran dalam rangka pelaksanaan APBN

Pemerintah Republik Indonesia. (2018). Peraturan Menteri Keuangan Republik Indonesia nomor 196 tahun 2018 tentang tata cara pembayaran dan penggunaan kartu kredit pemerintah

Pemerintah Republik Indonesia. (2018). Peraturan Pemerintah Republik Indonesia nomor 50 tahun 2018 tentang perubahan atas Peraturan Pemerintah nomor 45 tahun 2013 tentang tata cara pelaksanaan anggaran pendapatan dan belanja negara.

Pemerintah Republik Indonesia. (2019). Peraturan Pemerintah Republik Indonesia nomor 231 /PMK.03/2019 tentang tata cara pendafaran dan penghapusan nomor pokok wajib pajak, pengukuhan dan pencabutan pengukuhan pengusaha kena pajak, serta pemotongan dan/atau pemungutan, penyetoran, dan pelaporan pajak bagi instansi pemerintah

Pemerintah Republik Indonesia. (2017). Peraturan Direktur Jenderal Perbendaharaan nomor 17/PB/2017 tentang uji coba pembayaran dengan kartu kredit dalam rangka penggunaan uang persedia 